\title{
Meningkatkan Kemampuan Bicara Berbahasa Inggris Mahasiswa Dalam Mendeskripsikan Suatu Kegiatan Dengan Menggunakan Model Pembelajaran Presentation Practice Produce (PPP)
}

\author{
Depi Prihamdani, Ss., M.Pd.
}

Pendidikan Guru Sekolah Dasar (PGSD), FKIP Universitas Buana Perjuangan, INDONESIA e-mail: depi.prihamdani@ubpkarawang.ac.id

Improving Students' English Speaking Ability in Describing an Activity by Using the Presentation Practice Produce (PPP) Learning Model

\section{Kata Kunci}

Berbicara, Bahasa Inggris dan Model Pembelajaran PPP

\section{Keywords:}

Speaking, English and PPP Learning Models

\section{Abstrak}

Tujuan penelitian ini adalah menjawab permasalahan bagaimana meningkatkan kemampuan berbicara bahasa Inggris mahasiswa yang bukan jurusan bahasa Inggris di Universitas Buana Perjuangan Karawang pada umumnya dan dikelas pada khususnya. secara khusus penelitian ini memiliki tujuan, yaitu: 1. Mengetahui faktor yang mempengaruhi kemampuan mahasiswa dalam bicara berbahasa Inggris. 2. Mengetahui efektifitas penerapan model pembelajaran presentation, practice, produce dalam meningkatkan keterampilan berbicara mahasiswa dalam berbahasa Inggris? 3. Mengetahui apakah penerapan model pembelajaran presentation, practice, produce dapat meningkatkan keterampilan berbicara mahasiswa dalam mendeskripsikan sesuatu dengan menggunakan bahasa Inggris. Metode penelitian yang digunakan adalah kualitatif deskriptif. Langkah-langkh yang dilakukan dalam penelitian ini; 1. Menentukan sample dari populasi (terjangkau), mahasiswa yang bukan jurusan bahasa Inggris di Universitas Buana Perjuangan Karawang. 2. Sample yang sudah ditentukan diberi pre-test kemampuan berbicara untuk mengetahui kemampuan awal mereka (mereka diminta untuk menceritakan suatu objek berdasarkan gambar yang diberikan). 3. Setelah hasil pre-test diperoleh, dilakukan pembelajaran dengan menggunakan metode presentation practice produce (PPP). 4. Kemudian dilakukan test untuk melihat hasil pembelajaran dengan menggunakan metode PPP.

\section{Abstract:}

The purpose of this study is to answer the problem of how to improve the English speaking ability of students who are not majoring in English at the University of Karawang Buana Struggle in general and in class in particular. specifically this study has a goal, namely: 1. Knowing the factors that affect students' ability to speak English. 2. Knowing the effectiveness of the application of learning, presentation, practice and produce learning models in improving students' speaking skills in English? 3. Knowing whether the application of the learning model of presentation, practice, produce can improve students' speaking skills 


in describing something using English. The research method used is
descriptive qualitative. The steps taken in this study; 1. Determine the
sample of the population (affordable), students who are not majoring
in English at the University of Karawang Buana Struggle. 2. The
predetermined sample is given a pre-test of speaking ability to find out
their initial ability (they are asked to tell an object based on the
picture given). 3. After the pre-test results are obtained, learning is
done using the presentation practice produce (PPP) method. 4. Then
the test is done to see the learning outcomes using the method.
Article History:
Received: 5 Januari 2019
Revised: 6 Februari 2019
Accepted: 10 Mei 2019

\section{Pendahuluan}

Karakteristik Bahasa Inggris berbeda dengan ilmu pengetahuan lainnya. Perbedaan tersebut terdapat pada fungsi bahasa sebagai alat komunikasi. Hal ini menunjukan bahwa belajar bahasa Inggris bukan hanya belajar kosa kata dan tata bahasa dalam arti pengetahuan, tetapi harus berupaya mengaplikasikan dan menggunakan dalam kegiatan sehari-hari sebagai alat komunikasi (Hansen: 1984). Dalam kehidupan sehari-hari, biasanya orang menilai kemampuan bahasa Inggris seseorang dari kemampuan bicara. Seseorang yang secara lancar dapat menyampaikan ide / gagasan dalam bahasa Inggris maka dikatakan mahir dalam berbahasa Inggris (Ersoz, Aydan : 2000).

Salah satu keterampilan berbahasa yang harus dikuasai mahasiswa adalah keterampilan berbicara. Namun, mengucapkan ungkapan atau kalimat bahasa Inggris yang sesuai dengan budaya Inggris tentu tidak mudah bagi sebagian mahasiswa yang bukan berlatar belakang pendidikan atau mempunyai pengetahuan atau minat bahasa Inggris karena secara universal ada perbedaan aksen, intonasi dan pola pikir antar bangsa. Penutur harus memahami konteks budaya dan konteks sosial dari pengguna bahasa tersebut sebagai latar belakangnya. Dalam hal ini, konteks budaya, aksen, intonasi dan situasi komunikasi yang berbeda sangat berpengaruh bagi kemampuan mahasiswa dalam mengucapkan kata atau kalimat bahasa Inggris.

Kemampuan berbicara bahasa Inggris mahasiswa yang bukan berlatar belakang bahasa Inggris di kabupaten Karawang masih rendah. Hal ini diindikasikan dengan masih banyaknya mahasiswa dalam mengekspresikan ide dengan menggunakan bahasa Inggris secara lisan sering terhenti di tengah pembicaraan, durasi bicara rata-rata di bawah 5 menit, menggunakan kosa kata sangat terbatas, kurang keberanian untuk memulai bicara dalam bahasa Inggris baik dalam bertanya maupun menjawab pertanyaan (memberikan penjelasan). Temuan peneliti yang berfokus pada transactional interpersonal dan functional menunjukkan bahwa mahasiswa hanya menjawab pada pokok gagasan saja, kurang dapat mengembangkan jawaban bahkan bertanya dalam bahasa Inggris. Singkatnya jawaban yang diberikan menunjukkan keterbatasan kosa kata, dan juga kemampuan berbicara bahasa Inggris yang masih rendah.

Model pembelajaran bahasa Inggris dengan menekankan pada presentasi, praktik dan produksi dalam pembelajaran bahasa Inggris sangat membantu pembelajar bahasa Inggris dalam membangun kemampuan yang dirasa cukup kompleks. Oleh karenanya menggunakan model 
pembelajaran Presentation Practice Produce (PPP) dalam meningkatkan kemampuan bahasa Inggris perlu untuk dilakukan. Peneliti melihat perlu untuk berupaya meningkatkan kemampuan bicara mahasiswa dengan menggunakan PPP ini diharapkan dapat meningkatkan komunikasi verbal dalam bahasa Inggris, sehingga kemampuan bicara mahasiswa dalam bahasa Inggris dapat ditingkatkan.

\section{Metode Penelitian}

\section{a. Jenis Penelitian}

Penelitian ini bertujuan untuk mengetahui efektifitas metode pembelajaran PPP dalam meningkatkan kemampuan mahasiswa menggunakan bahasa inggris dalam berbicara. Penelitian ini menggunakan metode penelitian tindakan kelas.

\section{b. Tempat dan Subjek Penelitian}

Tempat dan subjek penelitian dilakukan terhadap mahasiswa semester II angkatan 2018 Universitas Buana Perjuangan Karawang yang beralamat di Jalan HS. Ronggowaluyo Desa Puseur Jaya, Teluk Jambe Timur, Karawang Barat, kabupaten Karawang, Jawa Barat. Website : www.ubpkarawang.ac.id

\section{c. Rancangan Penelitian}

Menurut Ary (2010:512) penelitian tindakan adalah tentang tindakan yang dilakukan berdasarkan penelitian dan meneliti tindakan yang dilakukan. Ada empat kegiatan yang dilakukan dalam prosedur penelitian tindakan kelas, yaitu; 1) Rencana kegiatan, 2) Pelakasanaan kegiatan, 3) Observasi, 4) Refleksi kegiatan. Arikunto (2010:131). Apabila siklus pertama tidak mencapai kriteria keberhasilan, maka dilaksanakan siklus ke dua.

\section{d. Prosedur Penelitian}

Berdasarkan rancangan penelitian, kegiatan penelitian dilaksanakan dalam beberapa tahapan, yaitu: 1) Studi pendahuluan, 2) Perencanaan, 3) Pelaksanaan, 4) Observasi, dan 5) Refleksi.

1. Studi pendahuluan

Berdasarkan hasil wawancara yang dilakukan terhadap mahasiswa angkatan 2018, lebih dari 70 persent dari mereka tidak suka dengan bahasa Inggris. Dengan arti kata bahwa mereka tidak bisa berbahasa Inggris.

\section{Perencanaan kegiatan}

Langkah pertama penelitian adalah perencanaan kegiatan, sebelum melaksanakan kegiatan di kelas, peneliti menyiapkan kegiatan sebagai berikut;

a. Memilih topic berdasarkan jenis teks (deskriptif) untuk mengajar speaking.

b. Memilih materi yang digunakan dalam mengajar speaking yang diambil dari berbagai sumber berdasarkan tema.

c. Membuat rencana perkuliahan untuk kegiatan pertama dan kedua pada siklus pertama.

d. Menyusun kriteria keberhasilan.

e. Membuat rubrik penilaian ujian speaking. 
Improving Students' English Speaking Ability in Describing an Activity by Using the Presentation Practice Produce (PPP) Learning Model

3. Pelaksanaan Kegiatan

Kegiatan siklus pertama dilaksanakan sesuai dengan rencana perkuliahan pertama dan kedua. Sedangkan kegiatan siklus kedua berdasarkan pada peninjauan ukang renacana perkuliahan tiga dan empat. Setiap pertemuan diberikan waktu 90 menit.

4. Obervasi kegiatan

Pada penelitian tindakan kelas observasi dilakukan untuk mengamati pelaksanaan kegiatan penelitian. Data yang diperoleh pada penelitian ini adalah data kuantitatif, skor mahasiswa yang diperoleh dari pengamatan peneliti terhadap cara mahasiswa mendeskripsikan kegiatan pada gambar yang meliputi fluency (kelancaran), vocabulary (kosakata), pronunciation (pengucapan) dan grammar (tata bahasa), dan data kualitatif (aspek evaluasi), pengamatan yang dilakukan peneliti terhadap aspek evaluasi selama perkuliahan di kelas.

5. Refleksi

Refleksi adalah kegiatan menganalisa hasil observasi dan tes untuk mengetahui perkembangan sejaumana keberhasilan memecahkan masalah atau sebaliknya faktor apa yang menyebabkan ketidak berhasilan.

Untuk mengukur prosentasi skor berbicara siswa peneliti menggunakan rumus:

$E=\underline{n \times 100 \%}$

$\mathrm{N}$

Dimana:

E : Prosentasi siswa yang memperoleh skor $\geq 70$

$\mathrm{n}$ : Jumlah skor berbicara siswa yang memperoleh $\leq 70$

$\mathrm{N}$ : Jumlah total siswa

(Sumber; Ali: 1993:86)

6. Kriteria Keberhasilan

Kriteria keberhasilan digunakan untuk mengetahui apakah tujuan kegiatan diterima adalah: Skor target kemampuan berbicara siswa $\geq 70$. Penelitian ini akan berhasil jika prosentasi siswa yang mencapai nilai standar minimum mencapai 75 \%. Jika persyaratan diatas tidak tercapai pada siklus I, Kegiatan akan dilanjutkan pada siklus 2 .

7. Instrumen Penelitian

Instrumen yang digunakan pada penelitian ini adalah tes dan ceklis observasi. Data penelitian diperoleh dari skor tes berbicara subjek penelitian dan menggunakan ceklis observasi yang fokus pada pelaksanaan proses perkuliahan peneliti dengan menggunakan metode pembelajaran PPP.

Peneliti melakukan tes dengan meminta mahasiswa mengulang cerita dengan menggunakan kalimat mereka sendiri secara individu. Aspek penilaian yang digunakan meliputi kelancaran (fluency), tata bahasa (grammar), pengucapan (pronunciation), dan kosakata (vocabulary).

Ceklis observasi digunakan untuk menilai aktifitas peneliti selama proses perkuliahan di dalam kelas. Yang merupakan catatan kegiatan peneliti dan proses perkuliahan di kelas yang direfleksikan pada saat kegiatan dan tes. Ceklis observasi 
digunakan untuk menilai apakah peneliti sudah melakukan langkah-langkah pembelajaran berbicara di kelas sebagaimana metode yang akan diobservasi. Formulis ceklis observasi adalah sebagai berikut:

Tabel 1.1

Ceklis Observasi

\begin{tabular}{|l|l|l|l|}
\hline No & \multicolumn{1}{|c|}{ Aspek Evaluasi } & Yes & No \\
\hline 1 & Warming up (asking the students' favorite story). & & \\
\hline 2 & Writing suggestions given by the students. & & \\
\hline 3 & $\begin{array}{l}\text { Helping students mention generic structures and explain } \\
\text { language feature of the text. }\end{array}$ & & \\
\hline 4 & $\begin{array}{l}\text { Using cue response drill in explain language features of } \\
\text { descriptive text. }\end{array}$ & & \\
\hline 5 & Helping students to translate the difficult words & \\
\hline
\end{tabular}

8. Uji Validitas

Untuk mengetahui apakah soal yang akan diujikan valid atau tidak, pada penelitian ini dilakukan uji validitas soal. Menurut Arikunto (2010:211) Sebuah soal disebut valid apabila soal tersebut dapat mengukur apa yang seharusnya diukur.

9. Uji Riliabilitas

Untuk uji riliabilitas pada penelitian ini digunakan rumus alfa. Rumus alfa digunakan untuk mengetahui riliabilitas instrument, yang nilai skornya bukan merupakan 1 dan 0 .

Rumus Alfa:

$$
r_{11}: \frac{K}{K-1} \frac{\left(1-\sum s 1 b^{2}\right)}{s^{2} t}
$$

Dimana:

$r_{11}$ : Riliabilitas instrument

$K$ : Jumlah soal kuisioner

$\Sigma s b^{2} \quad$ : Varian soal

$s^{2} t:$ Total varian

(Sumber, Arikunto, 2010:239)

Setelah menghitunh riliabilitas terhadap tes ujicoba yang diberikan kepada mahasiswa, diperoleh hasil riliabilitas ujicoba dan perhitunganya, riliabilitas tes yang diperoleh adalah $0,744\left(r_{11}=0,744\right)$. Sedangkan menurut table kriteria tes dapat disimpulkan bahwa riliabilitas tinggi dan tes riliabel. 
Improving Students' English Speaking Ability in Describing an Activity by Using the Presentation Practice Produce (PPP) Learning Model

\section{Hasil dan Pembahasan}

\section{a. Hasil Penelitian Pendahuluan}

Berdasarkan hasil wawancara dan data skor mahasiswa, hanya 9 dari 30 mahasiswa yang memperoleh skor standar dari persyaratan (SKM=65).

\section{b. asil Siklus 1}

Observasi yang dilakukan oleh peneliti bertujuan untuk mengetahui apakah kegiatan proses belajar mengajar berbicara dengan menggunakan metode PPP berhasil atau tidak dalam meningkatkan kemampuan berbicara mahasiswa. Namun ada dua aspek evaluasi yang dilakukan yaitu, menggunakan dril respon klu dalam menjelaskan ciri-ciri Bahasa teks deskriptif dan memberikan terjemahan terhadap kata-kata sulit. Dengan kata lain bahwa peneliti gagal jika kedua aspek evaluasi tersebut tidak terpenuhi pada siklus 1. Dengan demikian penelitian harus merevisi pada siklus 2 . Pada siklus 1 ini terdapat 12 mahasiswa yang mencapai skor target atau $40 \%$.

\section{c. Hasil Siklus 2}

Berdasarkan observasi ceklis pada siklus 2, selama proses belajar dan mengajar peneliti memberikan penjelasan dan instruksi yang jelas kepada mahasiswa dan mampu mengontrol mahasiswa dengan lebih baik daripada pada siklus 1 . Peneliti melaksanakan semua aspek pada ceklis observasi. Dengan kata lain bahwa siklus ke-2 berhasil dan semua aspek evaluasi terpenuhi. Sebanyak 23 atau 77,28\% dari mahasiswa memperoleh skor target. Dengan demikian, dapat disimpulkan bahwa kegiatan pada penelitian ini berhasil dan tidak perlu melakukan siklus berikutnya.

\section{d. Pembahasan}

Berdasarkan hasil uji berbicara pada siklus 1, terdapat 12 dari 30 mahasiswa atau 40\% mahasiswa yang mendapatkan skor $\geq 70$ mencapai skor target, berarti bahwa siklus 1 tidak berhasil.

Berdasarkan hasil observasi uji ceklis selama siklus 1 , peneliti tidak menggunakan dril respon klu dan tidak memberikan terjemahan pada mahasiswa. Hal ini menimbulkan kesulitan pada mahasiswa dalam memahami teks.

Maka, untuk implementasi lebih baik dilakukan beberapa revisi pada siklus ke-2, sebagaimana penjelasan berikut ini:

Pertama, peneliti melibatkan mahasiswa dalam proses belajar mengajar yang membuat kelas lebih efektif, meminta mahasiswa untuk mengungkapkan ide-ide mereka tanpa malumalu. Ketika peneliti menjelaskan materi perkuliahan, peneliti bertanya "What is your favorite story? Langkah ini disebut pemanasan. Menurut Nascimento (2010) (yang diterjemahkan), "Tingkatan presentasi biasanya terdiri dari 2 tahap; Kegiatan pendahuluan seperti pemanasan atau memimpin sebuah kegiatan yang bertujuan untuk meningkatkan minat mahasiswa pada topik pembahasan; dan pengenalan Bahasa target. Kemudian mahasiswa menyebutkan setiap jenis cerita sesuai kemauan mereka. Setelah itu peneliti menuliskannya di papan tulis. Dosen memilih satu dari cerita yang disebutkan mahasiswa dan menjelaskan fitur Bahasa dan struktur generic cerita tersebut. Kemudian peneliti menggunakan teknik dril respon isyarat dan meminta mahasiswa membuat kalimat bentuk lampau (past). Dengan kata lain, mahasiswa mengulang 
sebagian kalimat, biasanya frasa terakhir baris kalimat. Selanjutnya, mengikuti isyarat dosen, mahasiswa mengembangkan setiap bagian yang mereka ulang sampai mereka mampu mengulang kesemua baris kalimat (Larsen \& Freeman, 2000:48). Kegiatan ini bias mendorong mahasiswa untuk berbicara. Selanjutnya membantu mahasiswa menterjemahkan kata-kata sulit.

Kedua, memberikan terjemahan atas kata-kata sulit. Catford dalam Suryawinata (2003:11) mengatakan bahwa terjemahan adalah pengganti materi tekstual dalam satu Bahasa dari persamaan materi tekstual dengan Bahasa yang lain. Karena itu, terjemahan dapat membantu mahasiswa mudah memahami materi dan membuat mahasiswa tertarik ketika dosen menggunakan cerita sebagai media dalam perkuliahan. Kemudian, peneliti menggunakan berbagai jenis metode pembelajaran. Pada materi praktik mahasiswa tidak hanya focus pada latihan menulis tetapi juga diikutsertakan pada kelas percakapan. Yang terakhir dengan presentasi yang baik dan praktik, mahasiswa dapat membuat kalimat untuk mengulang cerita dengan menggunakan kata-kata mereka sendiri.

Siklus 2 dilakukan sebagai revisi dari siklus 1 . Sedangkan, hasil uji berbicara pada siklus 2 , terdapat 23 dari 30 mahasiswa memperoleh nilai $\geq 70$ atau (77.37\%). Dengan demikian, bias dikatakan bahwa siklus 2 berhasil karena lebih dari 75\% mahasiswa memperoleh skor target $\geq$ 70 .

Dapat diketahui bahwa hasil yang dicapai karena dosen menggunakan metode PPP selama kegiatan pembelajaran berbicara, dan hasil ceklis observasi peneliti melaksanakan semua aspek evaluasi. Peneliti menggunakan dril respon isyarat didalam membuat kalimat dan menterjemahkan kata-kata sulit. Dengan demikian, mahasiswa menjadi lebih antusias praktik berbicara.

\section{Kesimpulan}

Berdasarkan hasil uji berbicara dan pembahasan pada bab IV dari penelitian ini, dapat diambil kesimpulan bahwa mengajarkan berbicara Bahasa Inggris dengan menggunakan metode PPP dapat meningkatkan kemampuan berbicara mahasiswa. Cara menggunakan metode ini adalah menerapkan metode PPP dengan menggunakan dril respon isyarat dalam membuat kalimat dan memberitahukan terjemahan kata-kata sulit kepada mahasiswa.

Memperhatikan kesimpulan diatas, bahwa menggunakan metode PPP dapat meningkatkan kemampuan berbicara mahasiswa.

\section{Daftar Pustaka}

Aleksandrzak, M. 2011. Problems and Challenges in Teaching and Learning Speaking at Advance Level. Gtottodidactica Xxxvii. Adam Mickiewics University Press Arizona.

Ali, Mohammad. 1993. Strategi Penelitian Pendidikan. Bandung: Penerbit Angkasa.

Arikunto, Suharsimi. 2010. Prosedur Penelitian: Suatu Pendekaan Praktik. Jakarta: Rineka Cipta.

Ary, Donald, et.at. 2010. Introduction to Research in Education. Canada: Nelson Education, Ltd.

Dimyati dan Mudjiono. 2009. Belajar dan Pembelajaran. Jakarta: Rineka Cipta. Davies, Ivor K., 1981. Instruction Technique, USA : McGraw Hill.

Good and Borphy. 1990. Educational Psychology, A Realistic Approach, London : Longman. Harmer, J. 2007. The Practice of English Language Teaching. Harlow: Longman Margono, S. 2009. Metedologi Penelitian Pendidikan. Jakarta: Rineka Cipta. 
Improving Students' English Speaking Ability in Describing an Activity by Using the Presentation Practice Produce (PPP) Learning Model

ReigeluthC, harles M. 1983. Instructional-DesigTheories and Models: An Overview of Their Current Sfafus. London. Lawrence Erlbaum Asociates.

Richards J.C. dan Renandya W.A. 2002. Methodology in Language Teaching: An Anthology of Current Practice. Cambridge University. Press

Suherman, E, dkk. 2004. Strategi Pembelajaran Bahasa Inggris Bandung: IMSTEP JICA

Syah, M uhibbin.1995. Psikologi Pendidikan. Bandung: Remaja Rosdakarya 